Bangladesh Journal of Anatomy January 2009, Vol. 7 No. 1 pp. 34-36

\title{
Position of Vermiform Appendix: A Postmortem Study
}

\author{
Uttam Kumar Paul ${ }^{1}$, Humaira Naushaba ${ }^{2}$, Tahmina Begum³ ${ }^{3}$, Md. Jahangir Alam4, Afshan \\ Jesmin Alim ${ }^{5}$, Jesmin Akther ${ }^{6}$
}

\begin{abstract}
Context: Vermiform appendix is an organ with immunological function in the abdominal cavity which is variable in position and length. It is important in different disease processes, such as appendicitis, carcinoma and diverticulitis. Appendicitis is the most important clinical condition. Appropriate anatomical knowledge about vermiform appendix is important for surgeons, pathologists and other physicians for proper diagnosis and management of appendicitis and carcinoma.
\end{abstract}

Study design: Descriptive type of study.

Place and period of study: Department of Anatomy, Sir Salimullah Medical College Hospital, Dhaka, from January 2006 to June 2007.

Materials and methods: Sixty (60) human postmortem vermiform appendix, age ranging from 0 to 65 years. Samples were observed in situ in the unclaimed dead bodies within 24 hours of death.

Results: Retrocaecal position was highest (65\%) followed by pelvic (31.7\%) and post ileal (3.3\%). Subcaecal and pre ileal varieties were not found.

Conclusion: To establish a data for Bangladeshi people, future studies are necessary by using larger sample size from different age and sex groups. To determine position of vermiform appendix, sonological studies are also recommended.

Key words: position, vermiform appendix

\section{Introduction:}

The vermiform appendix is an organ of variable position. Histological differentiation of vermiform appendix showed that it is a specialized organ ${ }^{1}$. There is no definite rule about the position of the vermiform appendix, but it is thought that the position of the vermiform appendix is closely related to the development of caecum ${ }^{2}$. Some investigators claim that the retrocaecal and retrocolic positions are the commonest.

1. Assistant Professor (c.c.), Department of Anatomy, Sir Salimullah Medical College, Dhaka

2. Professor and Head, Department of Anatomy, Sir Salimullah Medical College, Dhaka

3. Lecturer, Department of Anatomy, Sir Salimullah Medical College, Dhaka

4. Assistant Professor (c.c.), Department of Anatomy, Sir Salimullah Medical College, Dhaka

5. Assistant Professor, Department of Anatomy, Bangladesh Medical College, Dhaka

6. Assistant Professor, Department of Anatomy, Ibrahim Medical College, Dhaka
Vermiform appendix performs some functions related to gastrointestinal tract, the main function being immunological. It has also been stated that vermiform appendix acts like tonsil. As tonsil guards the upper alimentary tract from bacteria, the vermiform appendix also guards the small intestine from bacteria present in the large intestine ${ }^{3}$.

According to Wakeley ${ }^{4}$, the positions of the vermiform appendix are as follows: (a) retrocaecal and retrocolic passes retroperitoneally behind the caecum and ascending colon, and is the commonest type (60\%), (b) pelvic tip of appendix passes downwards and medially, crosses right pelvic brim, and is the second commonest type (30\%), (c) splenic or ileal type tip of the appendix passes upwards and medially in front or behind the terminal part of the ileal (pre or post ileal) (12\%), (d) subcaecal and paracolic lies below caecum and tip ascends by the side of the ascending colon (2\%), and (d) midinguinal very rare type and tip of the appendix is directed vertically downwards (Fig.-1). 


\section{Materials and methods:}

The present study was performed on sixty (60) human vermiform appendix of Bangladeshi people. The study period was January 2006 to June 2007.

\section{Parameter}

Position of the vermiform appendix.

\section{Procedure of the study}

Determination of the position of the vermiform appendix

The study was done in situ in the cadavers, before the organ was displaced by manipulation and dissection from the right iliac fossa. The abdomen was opened by a long midline incision and the flaps were reflected to give a good view of the abdominal cavity along with its contents. The anterior caecal taenia coli acts as the best guide for the vermiform appendix. Although the relation of the base of the appendix to the caecum is constant, the position of the vermiform appendix was studied in relation to the caecum, the terminal parts of ileum and the direction of the tip of the appendix. Accordingly, the position of the vermiform appendices was noted.

\section{Results:}

Table I and Fig. 2 show the incidence of position of vermiform appendix. The percentage of position of vermiform appendix were $65 \%$ retrocaecal, $31.7 \%$ pelvic and $3.3 \%$ post ileal. Pre ileal and subcaecal varieties were not found.

Fig.-3, 4 and 5 show retrocaecal, pelvic and post ileal variety of vermiform appendix found in the present study.

\section{Table I}

Incidence of position of vermiform appendix $(n=60)$

\begin{tabular}{lcc}
\hline Position & Number (n) & Percentage (\%) \\
\hline Retrocaecal & 39 & 65.0 \\
Pelvic & 19 & 31.7 \\
Post ileal & 2 & 3.3 \\
Pre ileal & 0 & 0.0 \\
Subcaecal & 0 & 0.0 \\
\hline
\end{tabular}

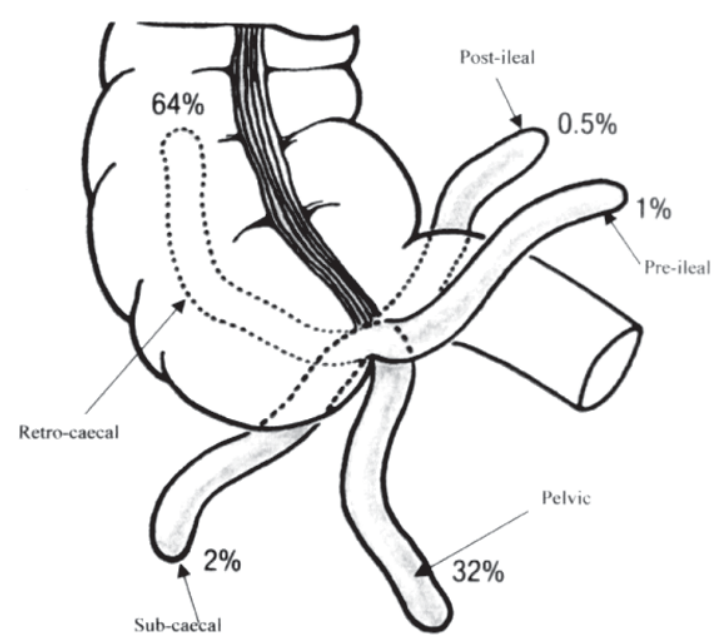

Fig. 1: Various positions of vermiform appendix 5 (from Agur and Dalley, 2005).

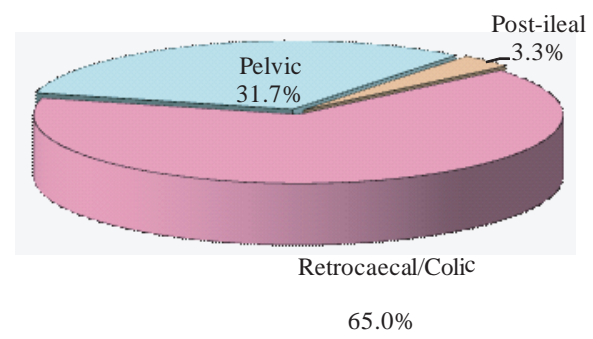

Fig. 2: Position of vermiform appendix

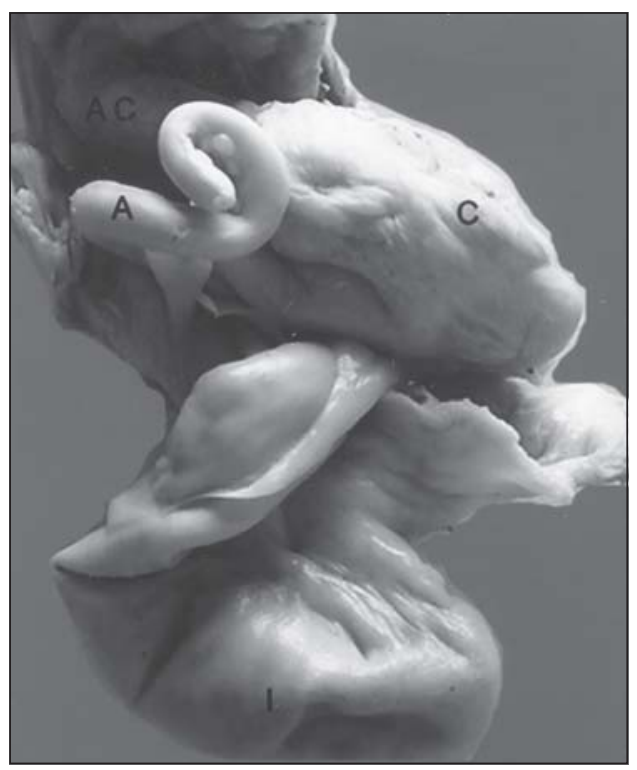

Fig. 3: Photograph showing the retrocaecal position of vermiform appendix $(A)$ and its relation with 


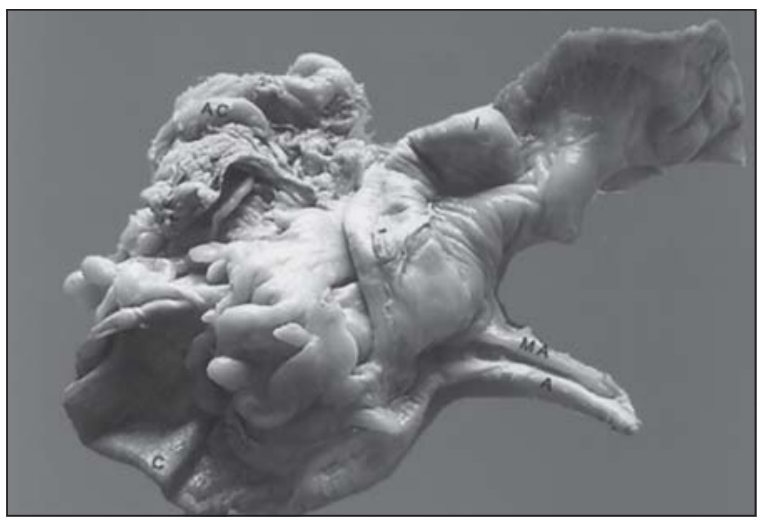

Fig.-4: Photograph showing the pelvic position of vermiform appendix $(A)$ and its relation with caecum (C) and ileum (I).

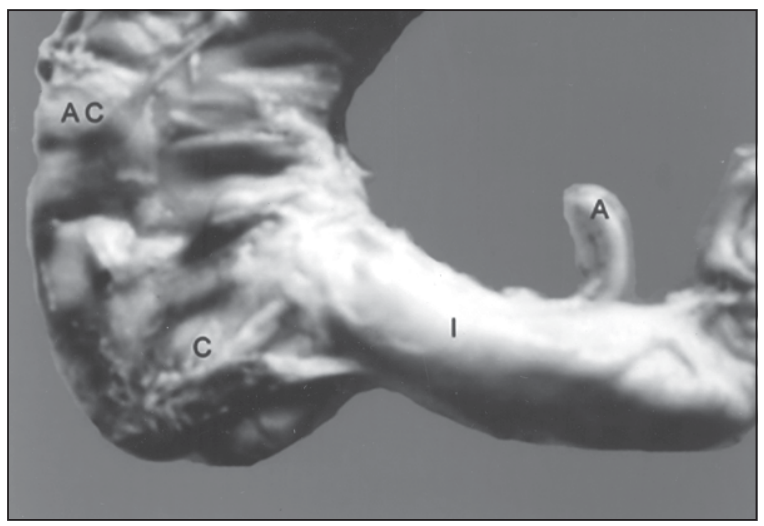

Fig. 5: Photograph showing the post ileal position of vermiform appendix $(A)$ and its relation with caecum (C), ileum (I) and ascending colon (AC).

\section{Discussion:}

In the present study, the retrocaecal position was highest (65\%) followed by pelvic (31.7\%) and post ileal (3.3\%). But the subcaecal and pre ileal varieties were not found.

The findings of the present study were similar to the findings by Wakeley ${ }^{4}$, Maisel ${ }^{6}$, Solanke ${ }^{7}$, Gladstone and Wakeley ${ }^{8}$ where retrocaecal position was higher than the pelvic variety. The present study did not coincide with the study which was carried out in Gorgan Teaching Hospital by Golalipour et al. ${ }^{9}$ where pelvic variety was $33.3 \%$, retrocaecal $32.4 \%$, preileal and subcaecal 12.8\%. Katzarski and Dutta $^{10}$ did a study on Ghanians where the pelvic variety was more and this can be explained by racial variation.

\section{References:}

1. Borley NR. Vermiform appendix. In: Standing $\mathrm{S}$, Ellis $\mathrm{H}$, Healy JC, Johnson D, Williams A, Collins P, et al., editors. Gray's anatomy: the anatomical basis of clinical practice. 39th ed. Edinburgh: Elsevier Churchill Livingstone; 2005. p.1189 90.

2. Moore KL, Dalley AF. Clinically oriented anatomy. 4th ed. Philadelphia: Williams and Wilkins; 1999. p.350 4.

3. Glover JW. The human vermiform appendix. TJ Arch 1988; 3(1): 318.

4. Wakeley CPG. The position of the vermiform appendix as ascertained by an analysis of 10,000 cases. J Anat 1933; 67: 27783.

5. Agur AMR, Dalley AF. Grants atlas of anatomy. 11th ed. Philadelphia: Lippincott Williams and Wilkins; 2005. p.132 6.

6. Maisel $\mathrm{H}$. The position of the human vermiform appendix in foetal and adult age groups. Anat Record 1960; 136: 3859.

7. Solanke TF. The position, length and content of the vermiform appendix in Nigerians. $\mathrm{Br} \mathrm{J}$ Surg 1970; 57(2): 1002.

8. Gladstone RJ, Wakeley CPG. The relative frequency of the various positions of the vermiform appendix: an ascertained by an analysis of 3,000 cases: with an account of its development. Br J Surg 1924; xi: 50320.

9. Golalipour MJ, Aray B, Azarhoosh R, Jahanshahi M. Anatomical variations of vermiform appendix in South East Caspian sea (Gorgan Iran). J Anat Soc India 2003; 52(2): 1413.

10. Katzarski M, Dutta CR. The vermiform appendix in Ghananians. Ghana Med J 1971; 4: 969. 